\title{
Aktivt dansk engagement
}

\section{Klaus Carsten Pedersen}

\section{Sovjetunionens opløsning har givet Danmark}

mere sikkerhed og medlemskabet af EU og NATO mere indflydelse end nogensinde før, og vi har brugt den, fx i Baltikum. Fodnoterne i NATO har vi lagt bag os, men desværre endnu ikke vore forbehold i EU

Nikolaj Petersen: Europæisk og globalt engagement - 1973-2003. Bind 6 i Dansk Udenrigspolitiks Historie. Gyldendal Leksikon, København, 2004. $661 \mathrm{~s}$.

Denne bog er en bedrift. En professor (nu emeritus) i statskundskab har skrevet et stykke gennemarbejdet, gedigen samtidshistorie. Det er ikke nogen let opgave. Det må være som at gå gennem et minefelt uden et ordentligt kort. Mange af periodens politiske kontroverser er jo ikke fordøjet endnu. Det gælder fx halvfjerdsernes EF-tilslutning, firsernes fodnotepolitik, halvfemsernes EU-forbehold og de seneste års engagement i Irak. Og den sikre vandring gennem dette minefelt besværliggøres af, at mange arkiver endnu ikke er tilgængelige. På den anden side er den tilgængelige mængde af meninger og informationer overvældende, og en anden analogi ligger lige for: vanskeligheden ved at se skoven for bare træer.

Men Nikolaj Petersen fører os tilsyneladende ubesværet gennem minefeltet, og ikke bare ser han skoven, han kortlægger den for os og viser os undervejs mange af de mest markante træer plus lidt af ukrudtet. Og det sker i noget så sjældent som et smukt, klart og nøgternt sprog, der er fuldkommen renset for politologisk og anden fagjargon. Bogen kan let læses af enhver interesseret i ét langt og fascinerende stræk. Dens klare og logiske struktur letter orienteringen og forståelsen, og det samme gør 153 relevante billeder, kort og tegninger. Disse kvaliteter samt en grundig litteraturvej- 
ledning og omfattende fortegnelser over litteratur, kilder og forkortelser burde give den vid udbredelse som lærebog.

Og endelig fungerer den fint som opslagsværk med i alt 20 sider indholdsfortegnelse, sted- og navneregister og sagregister.

\section{Overblik}

Det indledende afsnit med to kapitler hedder "Overblik 1973-2003" og lever helt op til titlen. Første kapitel er en fremragende indføring i udenrigspolitikkens vilkår, struktur og aktører og ville kunne stå alene som et fint essay i fx dette tidsskrift. Andet kapitel er en virkelig imponerende tyve siders tur gennem udviklingen i Danmarks omverden gennem de sidste sytten år af Den Kolde Krig 1973-1989 og den efterfølgende såkaldte ny verdensorden 1989-2001, derefter en hurtig gennemgang af den europæiske integration siden 1973 og endelig et blik på verden uden for Europa, den tredje verden og globaliseringen.

Hovedteksten er tredelt. Første del starter med Danmarks afgørende første skridt ind i den europæiske integrationsproces og giver den hjemlige baggrund og de grundlæggende præmisser, tilpasningen til de vigtigste politikker, slagsmålet om fiskeriet og ressourcerne på havbunden, valutaproblemerne og institutionerne i EF. For Danmark begynder således i 1970'- ernes europæiske samarbejde at trække mange tidligere udenrigspolitiske sager over mod indenrigspolitikken. Men samtidig deltager man nu i forsøgene på at udforme en europæisk udenrigspolitik, som får et særligt kapitel.

Man kan nævne det følgende kapitel om Norden og havet som et af mange eksempler på bogens kombination af overblik og grundighed i detaljen. Der gøres fx nøgternt rede for de problemer med rigets grænser til søs, som trænger sig på med de øgede tekniske muligheder for at udnytte olie- og gasforekomster under havet, og med det intensiverede internationale slagsmål om de stadig færre fisk i havet. I den omhandlede periode føres forhandlinger med Canada, Island og Norge omkring Grønland; Storbritannien, Island og Norge omkring Færøerne og Sverige, DDR og Polen i Kattegat og Østersøen. Der er naturligvis ikke blevet plads til alle detaljer. Man får ikke at vide, hvorfor grænsen til DDR må drages nærmere øen Bornholm end øen Rügen, eller hvad det er for særlige omstændigheder Polen påberåber sig, og som hidtil har umuliggjort fastlæggelsen af en dansk-polsk grænse.

\section{Hesselø og Taiwan}

Et af de muntre punkter på den dansk-svenske dagsorden er, om Hesselø rettelig kan indgå i den danske basislinje, hvorfra midtlinjen 
beregnes. Svenskerne hævder, at øen var ubeboet. Så meget og en del mere har Nikolaj Petersen med, men selvfølgelig ikke følgende anekdote, som han naturligvis kender.

Der boede faktisk nogen på øen, fyrpasseren og hendes mand, og daværende udenrigsminister Uffe Ellemann-Jensen kunne pege på det demografiske faktum, at øen havde en større befolkningstæthed end Sverige nord for Stockholm. Oluf Palme blev sur og omtalte på en pressekonference noget udiplomatisk Uffe som "denne danske overtjener". Ved en officiel middag kort tid senere i Stockholm rejste Uffe sig fra sin plads, lagde servietten over armen og gik hen til Palme og spurgte, hvad han måtte servere for herskabet. Så grinede Palme, og Uffe fik dagen efter en pung i de svenske farver. Sådan kan udenrigspolitik altså også være; men den slags supplerende kolorit må man opsøge andre steder.

Et kapitel om Danmark og den vide verden behandler FN og dansk bistandspolitik. Det følges af et kapitel, der symptomatisk for Danmarks ihærdige forsøg på at være lidt neutral samtidig med at man var allieret, hedder Danmark mellem øst og vest (ligesom en af Det Udenrigspolitiske Selskabs egne bøger dengang desværre kom til at hedde Danmark mellem supermagterne). Den grafiske fremstilling får man på Dyvig-rapportens omslag (1985), hvor en stor amerikansk raket "krydser klinge" med en stor sovjetisk raket over et lille, lysegrønt Danmark - en lille fredsommelig lus mellem to negle.

I dette kapitel gøres der bl.a. interessant rede for CSCE-processen og Danmarks forholdsvis fremtrædende rolle i den, og med udgangspunkt $\mathrm{i}$ anerkendelsen af DDR for en afgørende ændring af Danmarks anerkendelsespolitik. Man anerkender nu stater, og anerkendelsen beror ikke på, om man kan lide regimet, kun på, om det faktisk har effektiv kontrol med den pågældende stat, og med anerkendelsen af Nordvietnam og Nordkorea har Danmark realiseret et universalitetsprincip.

Nikolaj Petersen antyder dog hårfint, at det måske ikke helt er tilfældet. Det sker med formuleringen “... idet lande som Taiwan eller Rhodesia hævdedes at falde uden for den folkeretligt definerede uafhængighedsstatus". Mere siger han dog ikke om den sag.

Det operative ord er "hævdedes". Rhodesia var uafhængigt, men racistisk. Det hedder nu Zimbabwe og er igen racistisk og aldeles udemokratisk, men anerkendt. Taiwan var og er uafhængigt og er i dag demokratisk, men stadig ikke anerkendt. For Kina truer ikke bare med at smadre Taiwan, hvis det ikke godvilligt lader sig indlemme i Folkerepublikken, som er stor og anerkendt, men ikke demokratisk. Kina truer også ethvert land, der måtte finde på at anerkende Taiwan, med drabelige konsekvenser. 
Universalitetsprincippet er måske ikke så universelt, når det kommer til stykket, ligesom mange af vore såkaldte værdier måske ikke er så værdifulde, når store kommercielle interesser står på spil. Men sådan kan udenrigspolitik altså også være, og det havde nok været en kort diskussion værd - så meget mere som der også er en EU-vinkel på spørgsmålet. Europa-Parlamantet vil ligesom et stort antal folketingsmedlemmer og parlamentarikere over hele Europa gerne tage nogle positive skridt over for Taiwan; men en dertil svarende europæisk politik har regeringerne og Kommissionen ikke kunnet enes om. Det kunne jo ellers være en prøve på, om den fælles udenrigspolitik duer til noget.

\section{Krisestyring}

Afsnittet slutter med to kapitler på i alt 50 sider om alliance- og forsvarspolitikken i halvfjerdserne. Emnerne er den øgede trussel mod Danmark, forsvarsforligene og deres følger, planlægningen i Danmark og NATO, forstærkningspolitikken og kernevåbenpolitikken og kontroverserne omkring den. Det fortælles også, hvordan en dansk krisestyringspolitik bliver til; men her er anmelderen så heldig at kunne supplere bogens oplysninger. Begrebet krisestyring blev etableret i Danmark af Det Udenrigspolitiske Selskabs sikkerhedspolitiske studiegruppe, som i foråret 1973 afholdt et stort semi- nar om emnet med deltagelse af ministre og andre politikere, embedsmænd, officerer, universitetsfolk og journalister. Efterfølgende udgav man en pjece om emnet som den første samlede fremstilling om krisestyring på dansk.

Det var formodentlig seminaret, der ansporede til embedsmændenes arbejde med at strukturere et fleksibelt krisestyringssystem. Det bestod ganske rigtigt at tre niveauer: Regeringens Sikkerhedsudvalg bestående af de relevante ministre (altid statsministeren og udenrigs-, forsvars- og justitsministrene), Embedsmandsudvalget for Sikkerhedsspørgsmål (de samme ministeriers øverste chefer suppleret med cheferne for FE og PET) og nederst i hierarkiet arbejdshesten Sikkerhedspolitisk Kontaktgruppe (med de næunte ministerier og e-tjenesterne samt Forsvarskommandoen repræsenteret på kontorchefniveau og statsministerens sikkerhedspolitiske rådgiver som formand). Gruppen mødtes regelmæssigt for at koordinere situationsbilledet, diskutere udviklingen og konkrete tiltag og deltage i gennemførelsen af de store stabs- og kommandoøvelser, hvor den "spillede" Danmarks regering.

I en virkelig krise skulle den støtte departementscheferne og deres ministre døgnet rundt, hvor end krisestyringscentret måtte blive etableret. Det er således temmelig misvisende at betegne den som en studiekreds, og den sygnede ikke hen ef- 
ter kun 4-5 års forløb. Den forblev i det mindste fuldt aktiv frem til afslutningen af Den Kolde Krig.

\section{0'erne}

Derefter tager bogen hul på "de traumatiske firsere", som afsnittets indledende kapitel hedder, og vi får på 150 sider en dybt tilfredsstillende gennemgang af Danmarks situation og politik under Den Kolde Krigs kulmination og slutspil. Det alternative sikkerhedspolitiske flertals tilblivelse, aktiviteter og endeligt i perioden 1982-1988 gøres der grundigt rede for. Det er imponerende, at Nikolaj Petersen kan følge alle periodens spegede tråde, uden at han og vi mister overblikket. Det anbefales den interesserede, men læge læser at starte sit studium af Danmark under Den Kolde Krig her, inden hun eventuelt kaster sig ud i den store udredning fra DIIS, som udkom tidligere på året.

Det andet store emne i afsnittet analyserer forholdet til EF og det politiske slagsmål om Fællesakten. Det alternative sikkerhedspolitiske flertal valgte også at inddrage europapolitikken i sin oppositionsprofilering, men forregnede sig. Den borgerlige regering tog en folkeafstemning på spørgsmålet og vandt.

\section{Grønland og “Grønlandskortet”}

I et kapitel om de 'tunge' sager er der bl.a. en spændende gennem- gang af politiseringen af grønlandsk sikkerhedspolitik og moderniseringen af de amerikanske varslingssystemer i Grønland. I samme vending gennemgås også udviklingen efter indførelsen af Hjemmestyret i 1979, hvor den mest markante begivenhed var, at Grønland forlader EF den 1. januar 1985, efter at en folkeafstemning i februar 1982 havde givet et knebent flertal (52\%) for udmeldelse.

I den mellemliggende tid føres ualmindeligt seje forhandlinger om betingelserne for Grønlands udmeldelse og overgang til OLT-associering (en favorabel status for EF-tilknyttede oversøiske lande og territorier). I de følgende år får Grønland (og Færøerne) gradvis øget udenrigspolitisk indflydelse, og det spørgsmål trænger sig på, om de tre lande i Rigsfællesskabet kan føre hver sin uafhængige udenrigspolitik.

Nikolaj Petersen har særlige forudsætninger for at skrive om Grønland, som han har beskæftiget sig med i en årrække. Han nævner et andet sted i forbindelse med de amerikanske baserettigheder, at de "i danske øjne udgjorde et særligt bidrag til det vestlige forsvar, som skabte en kapital, der i givne situationer kunne trækkes på". Det er det såkaldte "Grønlandskort", som danske politikere og embedsmænd forsøgte at spille ud i betrængte situationer omkring NATO-bordet. Udtrykket "kapital" er lidt uheldigt 
valgt, eftersom det i Grønland er en udbredt antagelse, at det faktisk var og er milliarder værd for Danmark, penge som Danmark har fået lov til at spare på forsvarsbudgettet uden at blive smidt ud af NATO, og altså penge, som rettelig tilhører Grønland. Antagelsen er forkert. Danmark var ganske rigtigt ikke blandt NATOs big spenders; men man gjorde det nødvendige. Det indses let, at et gabende hul i vores del af Vesteuropas forsvar aldrig ville være blevet accepteret af vore allierede, ganske uanset hvor mange baser USA måtte have i Grønland.

Man kan vel i øvrigt diskutere, om "Grønlandskortet" overhovedet har kunnet spilles i en reel forhandlingssituation ud over den allerførste gang i 1951, hvor USA fik baserettigheder i en forsvarsaftale med Danmark, som er uopsigelig i NATOs levetid. Hverken Danmark eller Grønland kan altså true med at opsige den, men kan kun appellere til amerikanernes bedre jeg og gode vilje ved at minde dem om, hvor flinke vi var i 1951.

\section{0-2001}

Dette afsnit beskriver og analyserer den totale ændring af Danmarks sikkerhedssituation efter Den Kolde Krig og den hurtige og omfattende overgang til en aktiv og engageret udenrigspolitik. Truslen fra Sovjetunionen og Warszawa-pagten er væk, og Danmark er ikke længere en frontlinjestat i en kold krig med terrorbalance, men er rykket nærmere det europæiske centrum og nyder formentlig en grad af sikkerhed uden fortilfælde i sin lange historie.

Territorialforsvaret bliver langt mindre relevant, og forsvaret omdannes til at kunne indsættes fleksibelt langt fra Danmark til forsvar af danske og allierede interesser, herunder en acceptabel verdensorden. Danmark har fået mentalt overskud til at frigøre sig fra småstatspsykologien og til at erhverve sig indflydelse og gøre den gældende. Det sker overvejende med baggrund i medlemskabet af NATO og EU og i multinational ramme. Danmark etablerer sig som en regional og europæisk mellemmagt og som leverandør af sikkerhed og ikke længere kun modtager. Afsnittet gennemgår bl.a. fredsbevarelse i FN-ramme, den første Golfkrig, Balkankrigene og strukturreformerne i NATO.

Danmarks mest markante indsats i denne periode er uden tvivl hjælpen med at sikre de baltiske landes selvstændighed og demokratiske og $ø$ konomiske udvikling og med at få dem integreret i NATO og EU. Denne indsats sker både bilateralt, i nordisk ramme, i det Østersøråd, som Danmark og Tyskland tog initiativ til, i EU-kredsen og i NATO, og den er meget bredspektret. Også på dette område har Nikolaj Petersen særlige forudsætninger for at fremstille motiverne, processen og resultaterne, og man tør tro ham, når han 
slutter sin grundige gennemgang med at sige, at det er forholdsvis sjældent, at et mindre land får lejlighed til at spille en rolle som den, Danmark kom til at spille i Baltikum.

\section{EU: Forbeholdene og udvidelsen}

Europapolitikken kommer i krise, da folkeafstemningen i juni 1992 går EU imod med et nej-flertal på $50,7 \%$. Nikolaj Petersen fortæller, hvordan det går til, og hvordan der bliver reddet til hjørne med afstemning året efter på basis af de forbehold, som vi stadig trækkes med, uden at nogen kan eller bare forsøger at forklare, hvordan de tjener nationens interesser. Han hæfter sig ved, at kun en tredjedel af de socialdemokratiske vælgere fulgte partiledelsens anbefaling af et ja, og han foreslår, at det skyldes, at ledelsen og apparatet var svækket af formandsopgøret i foråret 1992.

Anmelderen vil gætte på, at det desuden kan bero på to andre faktorer, dels ledelsens udenrigspolitiske slingrekurs i 1980'ernes oppositionsrolle, dels at ledelsen af uransaglige årsager vælger at bryde ja-solidariteten i de sidste uger før afstemningen ved at gå i kødet på udenrigsministeren.

Uffe Ellemann-Jensen fremstår som periodens mest farverige og kontroversielle, men også mest betydningsfulde udenrigspolitiker, og som det fremgår af bogen, bliver hans aktive politik i Baltikum og på Balkan videreført efter den borgerlige regerings afgang i januar 1993 af regeringen Nyrup Rasmussen. Både statsministeren selv, udenrigsminister Niels Helveg Petersen og forsvarsminister Hans Hækkerup ønsker tydeligvis at lægge distance til 1980'ernes fodnotepolitik og kompensere for det svært forklarlige forbehold mod forsvarssamarbejde i EU.

Der gives selvfølgelig også en grundig behandling af hele processen frem mod EU's udvidelse med ti nye medlemmer, som umådelig professionelt forhandles på plads under det danske formandskab i andet halvår 2002 med den nye borgerlige statsminister Anders Fogh Rasmussen i førersædet sekunderet af udenrigsminister Per Stig Møller og hans embedsværk.

De danske forbehold analyseres ét for ét, og der sluttes af med ulandspolitikken og menneskerettighedspolitikken. Til sidst føres fremstillingen op til tiden efter den 11. september 2001 med dansk deltagelse i krigene i Afghanistan og Irak og de foreløbig forholdsvis resultatløse danske mellemøst-initiativer i 2002 og 2003. Modeordet globalisering forekommer heldigvis næsten ikke; men det er også en histore med 2-300 år på bagen. De sidste femten sider er en velskrevet opsummering, der ligesom indledningskapitlet ville kunne fungere fint som fritstående essay. 


\section{Civilsamfundet}

Det Udenrigspolitiske Selskabs grundlæggere havde den af 1930'erne og 1940'erne farvede opfattelse, at udenrigspolitik er for alvorlig til at den helt kan overlades til Udenrigsministeriet. Det har i løbet af de 30 år, bogen omhandler, holdt ca. 500 møder, gennemført 25 studierejser og løbende udgivet et udenrigspolitisk tidsskrift. Disse aktiviteter har forhåbentlig fra tid til anden gjort en lille forskel for Danmarks forhold til udlandet, men har formodentlig kun sat sig meget indirekte spor i dansk udenrigspolitik defineret som den danske stats udenrigspolitik og muligvis slet ingen i Udenrigsministeriets akter.

Anmelderen har derfor gjort lidt ud af krisestyringssagen, og et par andre sager skal kort nævnes. Da Dalai Lama i 1989 passerede København på vej til Oslo for at modtage Nobels Fredspris, var regeringen glad for at hilse på ham og mindes, at han havde fået en fin modtagelse året før. Det var dog ikke Udenrigsministeriets skyld. Det havde tværtimod lagt pres på Det Udenrigspolitiske Selskab for at få det til at aflyse et møde med ham, som Kinas ambassade havde protesteret voldsomt imod. Men ministeriet kommunikerede mundtligt, så der ligger næppe noget papirspor på akterne.

Det er heller ikke sikkert, at akterne nævner, at selskabet i maj 1991 ved et meget lukket heldagsseminar udrustede den estiske forsvarsmini- ster til forestående forhandlinger med sovjetiske myndigheder i Moskva - eller at et russisktalende medlem af selskabets briefinggruppe kom til at deltage helt uofficielt i den estiske delegation. Selskabets baltiske kontakter var overvejende etableret i 1989 og 1990, hvor man gennemførte en stor studierejse til de tre baltiske republikker og mødtes med mange nøglepersoner.

Nikolaj Petersen siger i sit rigtig gode kapitel om baltikumpolitikken, at Udenrigsministeriet i en tidlig fase valgte at skubbe civilsamfundet foran sig. Nogle gange forholder det sig omvendt: Civilsamfundet går foran helt af sig selv og trækker - måske Udenrigsministeriet med sig.

Savner man overhovedet noget $\mathrm{i}$ denne bog? Måske lidt flere kort. Måske en lidt fyldigere behandling af $ø$ konomiens rolle i udenrigspolitikken og omvendt. En stor del af Udenrigsministeriets ressourcer bruges trods alt på eksportfremme (importører formodes at klare sig selv). Måske lidt mere fokus på civilsamfundets mulige betydning for forholdet til udlandet. Og sidst, men ikke mindst, havde man gerne fra netop denne forfatter for overblikkets skyld set en samlet fremstilling af grønlændernes og færingernes udenrigspolitiske ambitioner - og såvel deres som danskernes problemer med at virkeliggøre disse ambitioner inden for eller uden for Rigsfællesskabet. Men det kunne måske blive emnet for en ny publikation. 